\title{
Comparative analysis of proliferative and genetic alterations in a primary chordoid meningioma and its recurrence using locus-specific probes and AgNOR
}

\author{
ANA PATRÍCIA BARROS CORDEIRO ${ }^{1}$, FÁBIO P.E. DA SILVA ${ }^{1}$, JULIO CESAR PIECZARKA ${ }^{2,5}$, \\ CLEUSA YOSHIKO NAGAMACHI ${ }^{2,5}$, NILSON PRAIA ANSELMO ${ }^{3}$, JOSÉ REGINALDO BRITO ${ }^{4,6}$, \\ DOUGLAS S. VASCONCELOS ${ }^{4,6}$, THOMAS LIEHR ${ }^{7}$, ANJA WEISE $^{7}$ and EDIVALDO H.C. DE OLIVEIRA ${ }^{2}$ \\ ${ }^{1}$ Pós Graduação em Genética e Biologia Molecular, ${ }^{2}$ Laboratório de Citogenética, ${ }^{3}$ Laboratório de Biologia Molecular, \\ ${ }^{4}$ Pós Graduação em Neurociências e Biologia Celular, Instituto de Ciências Biológicas, Universidade Federal do Pará, \\ Belém, PA; ${ }^{5}$ Bolsista Pesquisador, CNPq; ${ }^{6}$ Hospital Ophir Loyola, Belém, PA, Brazil; \\ ${ }^{7}$ Institut für Humangenetik und Anthropologie, Jena, Germany
}

Received October 9, 2008; Accepted January 20, 2009

DOI: $10.3892 / \mathrm{mmr} 00000120$

\begin{abstract}
Meningiomas are generally slow-growing benign tumours; however, recurrent cases are associated with a poor prognosis. As these tumours are commonly grouped according to their grade of malignancy, it is difficult to define tumourspecific alterations involved in their genesis and evolution. Genetic comparative studies of primary and recurrent tumours are important for the identification of the chromosomal, genetic and proliferative alterations that are possibly involved in the process of malignancy in this class of tumour. We performed interphase fluorescence in situ hybridization using region-specific probes comprising the genes $M Y C N, E R B B 4$, $C D H 1, A B R, E R B B 2$ and $N F 2$ as well as AgNOR staining in a sample of primary and relapsed chordoid meningiomas. Significant differences were found in these samples regarding the genes NF2, MYCN, ABR and ERBB2. Cell proliferation levels also showed a significant difference. The results suggest the involvement of the MYCN gene in the evolution of meningiomas.
\end{abstract}

\section{Introduction}

Meningiomas are the most frequently occurring non-glial brain primary tumours, benign in $90 \%$ of cases and presenting slow growth $(1,2)$. It is well-known that total or partial monosomy 22 is the most consistent chromosomal aberration found in meningiomas (2-5). Other chromosomal alterations include deletions of $1 \mathrm{p}, 3 \mathrm{p}, 6 \mathrm{q}, 9 \mathrm{p}, 10 \mathrm{q}$ and $14 \mathrm{q}(4,6-11)$.

Correspondence to: Professor Edivaldo H.C. de Oliveira, Laboratório de Citogenética, Instituto de Ciências Biológicas, Universidade Federal do Pará, Rua Augusto Correa 01, CEP 66075990, Belém, PA, Brazil

E-mail: ehco@ufpa.br

Key words: meningioma, mutations, $M Y C N, N F 2$, tumour relapse
Mutations in the tumour suppressor gene NF2 were detected in more than $60 \%$ of sporadic meningiomas $(2,5,12-14)$. Other uncommon molecular alterations include the deletion of the genes PTEN (10q23) and CDKN2C (1p32), and amplification of the gene PS6K (17q23) $(6,15,16)$.

Chordoid meningiomas (WHO grade II) contain regions histopathologically similar to chordomas, intercalated with meningioma-typical regions (17). Relatively little genetic information is available regarding this specific type of tumour, although reverse FISH studies in three chordoid meningiomas revealed a $\operatorname{der}(1) \mathrm{t}(1 ; 3)(\mathrm{p} 12-13 ; \mathrm{q} 11)$ in all samples and monosomy of chromosomes 6, 10, 11, 18 and 22 in one of the cases (18). Factors apparently associated with meningioma recurrence include malignant histology, high proliferation levels of tumour cells, unfavourable tumour localization, incomplete surgical dissection and monosomy 14. However, recurrence is still observed in histopathologically benign tumours and in tumours without monosomy $14(19,20)$, as well as after complete resection (21). Usually, recurrence is associated with a poor prognosis (22).

Cell proliferation studies using AgNOR staining have been used to establish a positive correlation between the increased average number of nuclear organizer regions (NORs) in nuclei and aggressivity and/or poor prognosis. Some examples of the application of this technique have been published concerning oral cancer (23), uterine lesions (24) and nervous system tumours (25-28).

The aim of this study was to investigate cell proliferation levels using AgNOR staining, as well as the occurrence of amplification/deletion of chromosome regions, including the genes MYCN and ERBB4 (chromosome 2), CDH1 (chromosome 16), $A B R$ and $E R B B 2$ (chromosome 17) and $N F 2$ (chromosome 22), by applying interphase FISH in a case of chordoid meningioma and its relapsed tumour.

\section{Materials and methods}

Case report. This analysis was conducted with the approval of the CEP-CCS/UFPA Committee (029/06). A 36-year-old 
Table I. Characterization of the selected probes and types of tumours in which the genes showed some degree of alteration.

\begin{tabular}{lllr}
\hline Probes/genes & Location & Type of tumor & Refs. \\
\hline NF2 & $22 \mathrm{q} 12.2$ & Meningiomas & 17 \\
Control & $22 \mathrm{q} 11.23$ & Meningiomas & 17 \\
$C D H 1$ & $16 \mathrm{q} 22.1$ & Meduloblastomas & 36 \\
$A B R$ & $17 \mathrm{p} 13.3$ & Meduloblastomas & 32 \\
$E R B B 2$ & $17 \mathrm{q} .21 .1$ & Gliomas & 35 \\
$M Y C N$ & $2 \mathrm{p} 24.1$ & Glioblastoma multiforme & 33 \\
$E R B B 4$ & $2 \mathrm{q} 33.3-\mathrm{q} 34$ & Meduloblastomas & 34 \\
\hline
\end{tabular}

woman was repeatedly surgically treated for the presence of a meningioma at the Hospital Ophir Loyola (Belém, PA, Brazil). Both primary and recurrent tumours were resected subtotally. The second surgery occurred three months after the first. The patient was not treated by chemotherapy/radiotherapy before or after any of the surgeries. Eighteen months after the second surgery, the patient is alive and without traces of re-incident tumours. Histopathologic analysis confirmed chordoid meningioma in both tumours according to the WHO classification $(17,29)$. A non-recurrent meningothelial meningioma sample and a lymphocyte culture from a healthy individual were used as controls (30). Consent for publication in print was obtained from the patient.

Cytological preparations. Interphase nuclei were obtained from tissue samples according to Ford and Hamerton (31), with modifications. Chromosome and interphase preparation from a healthy individual were obtained from standard lymphocyte cultures (RPMI-1640 medium, 72-h incubation, $0.2 \mathrm{mg} / \mathrm{ml}$ colcemid for $60 \mathrm{~min}$ ).

Interphase fluorescence in situ hybridization. Locus regionspecific FISH probes were chosen after careful review in previously published studies. They included genes that are involved in the genesis and development of various types of nervous system tumours (Table I) (17,32-36). For iFISH analysis, the locus-specific probes were obtained from BACs for genes MYCN (RP11-463P22), ERBB4 (RP11-44A23), CDH1 (RP11-401A12), ABR (RP11-216P06), ERBB2 (RP11-61O22) and NF2 (RP11-155B12). In addition, a probe from BAC in the 22q11.23 (RP11-464B20) region was used with the NF2 probe as a control for chromosomal alterations (37). All the probes were obtained from BAC PAC chori or the Sanger Centre and labelled with Texas Red or Fluorescein. Dual and single colour FISH and signal detection were carried out as described previously (38). Briefly, slides were dehydrated and incubated for $2 \mathrm{~h}$ at $65^{\circ} \mathrm{C}$. Standard techniques were used for denaturation, hybridization, stringency washes and detection. The material was counterstained with DAPI. Hybridization results were examined and analyzed using a Zeiss Axioplan2 fluorescent microscope and Smartcapture 4.1 software. For analysis, we used the criteria found in Carlson et al (39): nuclei of 2-3 different areas were examined in each experiment, totalling 80-120 nuclei. Regions with a high background level or without at least one signal of each probe were not included. Two distinct region-specific probes of the same chromosome (2, 17 and 22) were analyzed together and independently in order to offer additional information regarding these chromosomes (37).

AgNOR staining. Staining of NORs was performed according to Howell and Black (40). For each sample, 200 intact nuclei, chosen by chance, were analyzed using a Zeiss Axioplan microscope.

Statistical analysis. The levels of significance of the results of AgNOR and iFISH analysis in the different samples were verified by the non-parametric Mann-Whitney U test. Levels were considered significant at $\mathrm{p}<0.05$.

\section{Results}

Table II shows the results of the analysis of two distinct region-specific probes of the same chromosome $(2,17$ and 22). A simultaneous increase in the signal number of the two probes on the same chromosome was taken to indicate aneuploidy, while alterations in the number of signals of only one probe were considered deletions or amplifications of the gene without the occurrence of aneuploidy of its respective chromosome.

In peripheral blood lymphocytes, a very low frequency of altered of signals $(0-2.5 \%)$ was found for all the probes. In general, tumour tissues revealed high levels of alterations for chromosome 22 , reaching $62.9 \%$ in the meningothelial meningioma, $78.3 \%$ in the primary chordoid meningioma (PCM) and $98.2 \%$ in the recurrent chordoid meningioma (RCM) (Table II).

Alterations in chromosome 2 (genes MYCN and ERBB4) were less evident in all the samples; however, amplification of the gene $M Y C N$, including or not the deletion of gene ERBB4, was observed in $32.2 \%$ of nuclei in meningothelial meningioma, $29.7 \%$ of those in PCM and $35.6 \%$ of those in RCM. The gene ERBB4 was altered in fewer nuclei, and its deletion was more frequent than its amplification. The PCM and RCM did not exhibit significant differences $(\mathrm{p} \geq 0.05)$ for this gene.

The genes $A B R$ and ERBB2 (chromosome 17), when analyzed alone, showed normal results in $>50 \%$ of the nuclei in chordoid meningiomas; however, monosomy values for these genes in meningothelial meningioma reached 40.8 and $53.3 \%$, respectively.

The gene $\mathrm{CDH1}$ (chromosome 16) was normal in $\sim 40 \%$ of the meningioma samples. In recurrent chordoid meningioma, this gene was amplified in $45.8 \%$ of nuclei, while in the meningothelial meningioma it was deleted in $33.6 \%$.

NOR analysis revealed the number of signals rising from $1.88 \%$ in the lymphocyte cultured material to $3.31 \%$ in the RCM (Fig. 1A and B), with significant differences among the samples $(\mathrm{p}<0.05)$ (Table III).

\section{Discussion}

The analysis of alterations in gene dosage and expression in cancer can yield important insights into the mechanism of 
Table II. Number of signals (\%) for each probe per nucleus.

Chromosome 22

Number of signals

Number of nuclei (\%)

\begin{tabular}{|c|c|c|c|c|c|c|}
\hline$N F 2^{\mathrm{a}}$ & $\mathrm{CP}^{\mathrm{b}}$ & C L & $\mathrm{C} \mathrm{MM}$ & PCM & $\mathrm{RCM}$ & Possible conclusions \\
\hline 2 & 2 & $98.898 .8^{100}$ & $39.237 .1^{69.1}$ & $27.521 .7^{47.5}$ & $10.90 .8^{14.3}$ & Normal nucleus for both genes \\
\hline$>2$ & 2 & 1.3 & 32 & 25 & 13.4 & Amplification of $N F 2$ \\
\hline 2 & $>2$ & 0 & 1.0 & 1.7 & 0.8 & Amplification of control probe \\
\hline$>2$ & $>2$ & $1.30^{0}$ & $55.714 .4^{16.5}$ & 60.82021 .7 & $80.719 .3^{20.2}$ & Hyperploidia \\
\hline$<2$ & 2 & 0 & 0 & 0.8 & 0 & Deletion of $N F 2$ \\
\hline 2 & $<2$ & 0 & 1.0 & 4.2 & 9.2 & Deletion of control probe \\
\hline$<2$ & $<2$ & ${ }^{0} 0^{0}$ & $5.24 .1^{14.4}$ & ${ }^{11.7} 10.8^{30.8}$ & 8.48 .465 .5 & Partial or total monosomy \\
\hline$<2$ & $>2$ & 0 & 1.0 & 0 & 0 & NF2 deleted and control amplified \\
\hline$>2$ & $<2$ & 0 & 9.3 & 15.8 & 47.9 & NF2 amplified and control deleted \\
\hline \multicolumn{2}{|c|}{ U test $N F 2$} & \multicolumn{2}{|c|}{$5.7^{\mathrm{c}}$} & \multicolumn{2}{|c|}{$4.0^{c}$} & \\
\hline \multicolumn{2}{|c|}{ U test control } & \multicolumn{2}{|c|}{$0.4^{\mathrm{d}}$} & \multicolumn{2}{|c|}{$3.6^{\mathrm{c}}$} & \\
\hline
\end{tabular}

Chromosome 2

Number of signals

\begin{tabular}{|c|c|c|c|c|c|c|}
\hline$M Y C N^{\mathrm{a}}$ & $E R B B 4^{\mathrm{b}}$ & C L & $\mathrm{C} \mathrm{MM}$ & PCM & $\mathrm{RCM}$ & Possible conclusions \\
\hline 2 & 2 & 97.597 .597 .5 & ${ }^{64.3} 58.3^{89.6}$ & $51.546 .5^{73.3}$ & $40.631 .7^{62.4}$ & Normal nucleus for both genes \\
\hline$>2$ & 2 & 0 & 31.3 & 25.7 & 28.7 & Amplification of $M Y C N$ \\
\hline 2 & $>2$ & 0 & 0.9 & 0 & 1 & Amplification of $E R B B 4$ \\
\hline$>2$ & $>2$ & $1.31 .3^{1.3}$ & ${ }^{33} 0.9^{1.7}$ & 33.744 .0 & $49.513 .9^{15.8}$ & Hyperploidia \\
\hline$<2$ & 2 & 0 & 0 & 1 & 2 & Deletion of $M Y C N$ \\
\hline 2 & $<2$ & 0 & 5.2 & 5 & 7.9 & Deletion of ERBB4 \\
\hline$<2$ & $<2$ & $1.31 .3^{1.3}$ & $2.62 .6^{8.7}$ & $14.913 .9^{22.8}$ & $9.96 .9^{21.8}$ & Partial or total monosomy \\
\hline$<2$ & $>2$ & 0 & 0 & 0 & 1 & $M Y C N$ deleted and $E R B B 4$ amplified \\
\hline$>2$ & $<2$ & 0 & 0.9 & 4 & 6.9 & $M Y C N$ amplified and $E R B B 4$ deleted \\
\hline \multicolumn{2}{|c|}{$\mathrm{U}$ test $M Y C N$} & \multicolumn{2}{|c|}{$3.7^{\mathrm{c}}$} & \multicolumn{2}{|c|}{$2.0^{\mathrm{e}}$} & \\
\hline \multicolumn{2}{|c|}{ U test $E R B B 4$} & \multicolumn{2}{|c|}{$0.5^{\mathrm{d}}$} & \multicolumn{2}{|c|}{$1.0^{\mathrm{d}}$} & \\
\hline
\end{tabular}

Chromosome 17

Number of signals

\begin{tabular}{|c|c|c|c|c|c|c|}
\hline$A B R^{\mathrm{a}}$ & $E R B B 2^{\mathrm{b}}$ & C L & $\mathrm{C} \mathrm{MM}$ & $\mathrm{PCM}$ & $\mathrm{RCM}$ & Possible conclusions \\
\hline 2 & 2 & 100100100 & $4531.7^{42}$ & $66.366 .3^{72.5}$ & $55.848 .3^{60.8}$ & Normal nucleus for both genes \\
\hline$>2$ & 2 & 0 & 7.5 & 5.0 & 10 & Amplification of $A B R$ \\
\hline 2 & $>2$ & 0 & 1.7 & 0 & 1.7 & Amplification of $E R B B 2$ \\
\hline$>2$ & $>2$ & ${ }^{0} 0^{0}$ & $14.23 .3^{5.0}$ & $27.518 .8^{18.8}$ & $18.36 .7^{8.3}$ & Hyperploidia \\
\hline$<2$ & 2 & 0 & 2.5 & 1.3 & 2.5 & Deletion of $A B R$ \\
\hline 2 & $<2$ & 0 & 11.7 & 0 & 5.8 & Deletion of ERBB2 \\
\hline$<2$ & $<2$ & ${ }^{0} 0^{0}$ & $40.838 .3^{53.3}$ & $6.35 .0^{8.8}$ & $25.823 .3^{30.8}$ & Partial or total monossmy \\
\hline$<2$ & $>2$ & 0 & 0 & 0 & 0 & $A B R$ deleted and $E R B B 2$ amplified \\
\hline$>2$ & $<2$ & 0 & 3.3 & 3.8 & 1.7 & $A B R$ amplified and $E R B B 2$ deleted \\
\hline \multicolumn{2}{|c|}{$\mathrm{U}$ test $A B R$} & \multicolumn{2}{|c|}{$3.2^{\mathrm{e}}$} & \multicolumn{2}{|c|}{$2.9^{\mathrm{e}}$} & \\
\hline \multicolumn{2}{|c|}{$\mathrm{U}$ test $E R B B 2$} & \multicolumn{2}{|c|}{$5.6^{\mathrm{c}}$} & \multicolumn{2}{|c|}{$3.3^{\mathrm{c}}$} & \\
\hline
\end{tabular}


Table II. Continued.

Chromosome 16

Number of signals

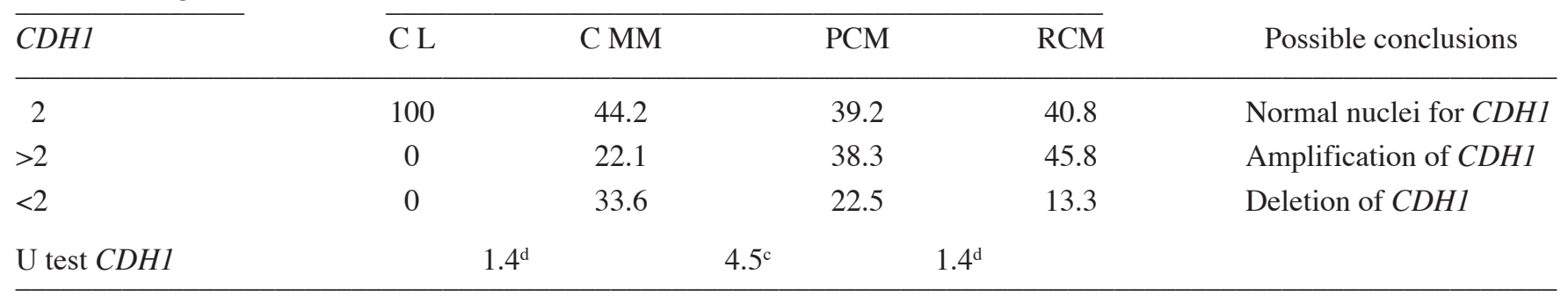

CP, control probe (BAC 22q11.23); C L, control (lymphocytes); C MM, control (meningothelial meningioma); PCM, primary chordoid meningioma; RCM, recurrent chordoid meningioma. ${ }^{n} \mathrm{X}^{\mathrm{n}}$, number of nuclei (\%) per category, independently considering ${ }^{\mathrm{a}}$ probe a and ${ }^{\mathrm{b}}$ probe $\mathrm{b}$, respectively. ${ }^{c}$ Highly significant difference between the samples $(\mathrm{p}<0.001)$. ${ }^{\mathrm{d}}$ No statistically significant difference between the samples

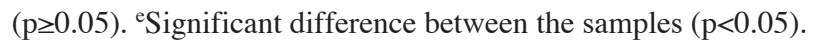

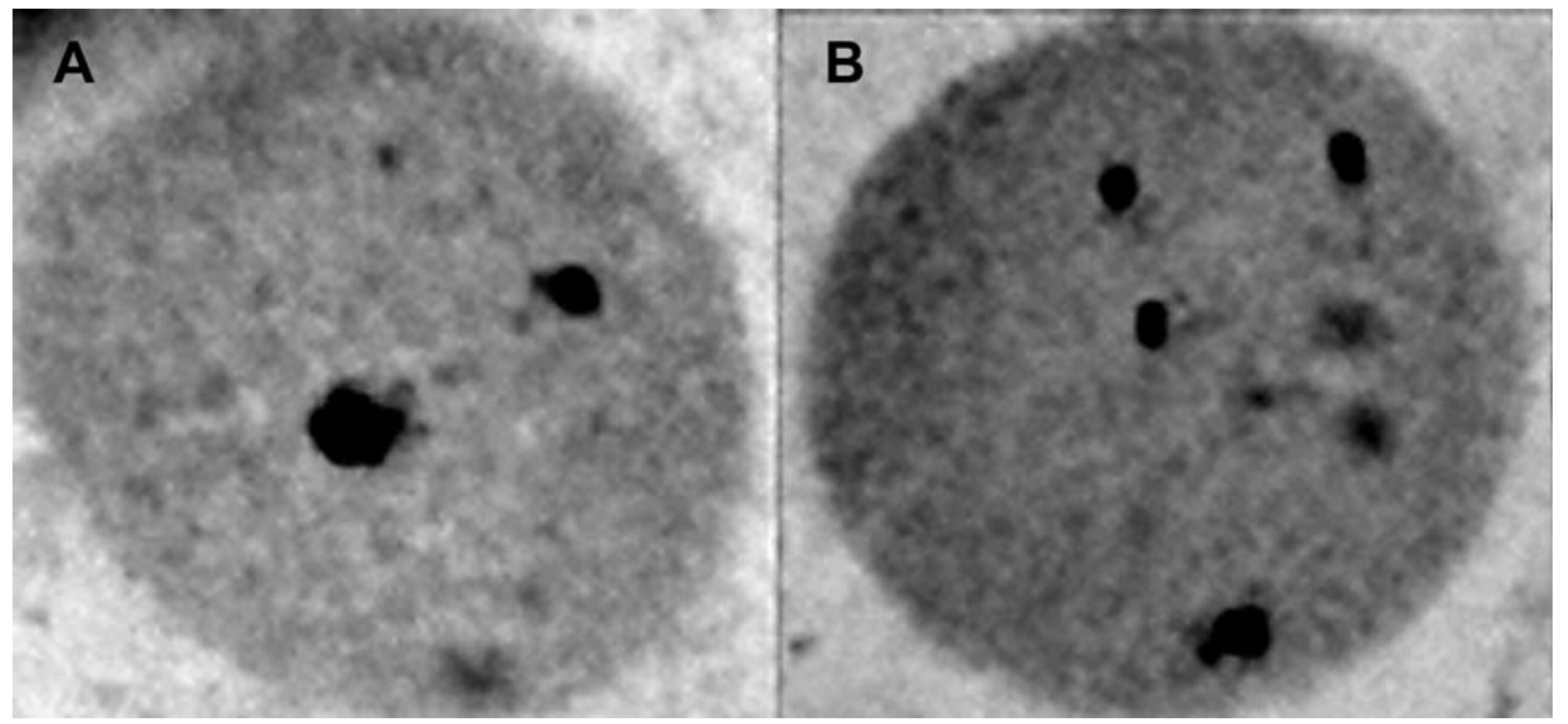

Figure 1. Cells submitted to AgNOR techniques show active nuclear organizer regions (NORs) as black dots: (A) two dots in a normal cell; (B) more than two dots in a cell from the meningioma.

Table III. Number of AgNOR signals (\%) per nucleus.

\begin{tabular}{|c|c|c|c|c|c|c|c|c|c|}
\hline \multirow[b]{2}{*}{ Sample culture } & \multicolumn{9}{|c|}{ Number of signals (\%) } \\
\hline & 1 & 2 & 3 & 4 & $\geq 5$ & $\mathrm{U}$ test & High/cell & Total signals & Media \\
\hline \multirow[t]{2}{*}{ C L } & 47.0 & 31.5 & 14.0 & 4.5 & 3.0 & & 7 & 376 & 1.88 \\
\hline & & & & & & $7.8^{\mathrm{a}}$ & & & \\
\hline \multirow[t]{2}{*}{$\mathrm{C} \mathrm{MM}$} & 5.5 & 50.0 & 25.5 & 13.5 & 5.5 & & 6 & 528 & 2.64 \\
\hline & & & & & & $2.1^{\mathrm{b}}$ & & & \\
\hline \multirow[t]{2}{*}{ PCM } & 22.5 & 37.0 & 24.0 & 7.0 & 9.5 & & 27 & 543 & 2.72 \\
\hline & & & & & & $6.0^{\mathrm{a}}$ & & & \\
\hline $\mathrm{RCM}$ & 7.0 & 23.0 & 31.5 & 22.0 & 16.5 & & 10 & 662 & 3.31 \\
\hline
\end{tabular}

C L, control (lymphocytes); C MM, control (meningothelial meningioma); PCM, primary chordoid meningioma; RCM, recurrent chordoid meningioma. High/cell, highest number of signals in one cell. aHighly significant difference between the samples $(\mathrm{P}<0.001)$. ${ }^{\mathrm{b}}$ Significant difference between the samples $(\mathrm{p}<0.05)$. 
tumorigenesis and new targets for therapy. Combined evidence indicates that aneuploidy plays a crucial role in these alterations and in initial events in the neoplastic process (1-3).

Meningioma genesis is usually associated with alterations in chromosomes 1, 3, 6, 9, 10 and 22, while anomalies in chromosome 14 reflects poor prognosis and a predisposition to recurrence $(2-4,7,9-11,21)$. Although these alterations have been identified, none can explain all cases of meningioma genesis or recurrence. This fact highlights the need for more studies on specific meningioma subtypes, as well as for the analysis of other genes, in particular those for which little information is available.

The most frequently altered gene among the meningiomas analyzed was $N F 2$, which was amplified in more than $80 \%$ of nuclei in the RCM. This finding is in disagreement with previous studies, which argued that partial or total monosomy 22 is the most frequent alteration in meningiomas (2-5). Our results indicate that distinct types of meningiomas may correspond to genetically heterogeneous groups. Tumor suppressor genes (TSGs) such as NF2 are negative regulators of cellular growth, and the inactivation of both alleles can confer advantage to the cell and promote neoplastic growth (4). Hence, amplifications of TSGs are not associated with tumorigenesis, unless a constitutional aberration, such as small deletions in NF2, could be involved in the inactivation of this gene prior to the gain of extra copies of chromosome 22 .

Two reports have been published to date concerning the cytogenetic analysis of the $M Y C N$ gene in meningothelial tumours. One used a cell line and did not observe significant alterations (41), and the second employed Southern blotting to analyze a paediatric meningioma (42). However, in the present study, alterations involving this gene, in particular amplifications, were observed in all the meningioma samples: meningothelial meningioma (35.7\%), PCM (48.5\%) and RCM (59.4\%). This fact could be indicative of a significant role for MYCN in the genesis and/or progression of some types of meningiomas.

The gene ERBB4, also found in chromosome 2, was altered to a much lesser degree in the neoplastic samples. When altered, this gene was in most instances deleted. Due to this discordance in the number of signals of the genes $M Y C N$ and $E R B B 4$, we can assume that the amplification of $M Y C N$ occurs without the involvment of the whole chromosome. In the literature, partial or total deletions of chromosome 2 were only related in one sample of fibroblastic meningioma (43) and in two samples of grade III meningioma (44).

The $A B R$ gene is functionally active in chromosome $17 \mathrm{p}$ (45). This gene was found deleted in seven of eight samples of medulloblastoma, which suggests the existence of other tumour supressor genes in this chromosome, apart from TP53 (32). In the present study, in meningothelial meningioma, the $A B R$ gene was normal or in monosomy in 45 and $40.8 \%$ of nuclei, respectively. A similar high incidence of monosomy was observed for $E R B B 2$, also found in chromosome 17. This fact suggests that chromosome 17 is in total or partial monosomy in approximately $40 \%$ of nuclei in this sample. It could be speculated that this partial or total monosomy observed in meningothelial meningioma is a secondary consequence of monoclonal carcinogenic expansion, or that this sample is actually polyclonal, which, in fact, has been observed in a few samples of meningioma (46). More samples must be analyzed if the role of $A B R$ in meningiomas is to be determined.

In chordoid meningiomas, the $\mathrm{CDH} 1$ gene was normal in nearly $40 \%$ of nuclei, and the frequency of amplification was higher than deletions in both samples. Although there are no previous cytogenetic reports involving this gene in this type of tumour, the results support the notion that the expression of this gene in recurrent tumours is identical to the expression observed in the primary tumour when there is no malign progression (47).

AgNOR analysis revealed a significant difference between meningothelial and chordoid meningiomas. This fact corroborates the proposal of Schiffer et al (48) that the high number of recurrences in atypical and anaplastic tumours depends on their high initial capacity for cell proliferation. The gradual increase in AgNOR index according to the increase in tumour grade observed in our results could reflect the great necessity for genetic transcription in these tumours, compatible with the level of cell propagation.

In conclusion, all the genes analyzed in this report showed some level of alteration in primary and recurrent chordoid meningiomas, with significant differences among the samples of the genes NF2, MYCN, ABR and ERBB2. Levels of cell proliferation among these neoplasias also showed significant differences. The results indicate that, although the differences are statistically significant, cell populations have similar genetic profiles. This corroborates Leuraud et al (30), who proposed a monoclonal origin for both initial and recurrent tumours.

Finally, our results reveal the need for a more intense analysis of the behavior of MYCN in some types of meningioma, as well as the total or partial monosomy of chromosome 17 as an alteration that occurs in a group of meningothelial meningiomas. The high incidence of amplification of NF2 observed, which conflicts with previous data, may indicate that meningiomas are heterogeneous and should be analyzed in subgroups.

\section{Acknowledgements}

We would like to thank Hospital Ophir Loyola (Belém, PA, Brazil) and the CEP-CCS/UFPA Committee. This work was partially supported by INTAS (AISbl 03-51-4060), UFPA and CNPq. We thank the Mapping Core group of the Wellcome Trust Sanger Institute for the initial clone supply and verification.

\section{References}

1. Kleihues P, Aguzzi A and Ohgaki H: Genetic and environmental factors in the etiology of human brain tumors. Toxicol Lett 82/83: 601-605, 1995 .

2. Louis DN, Scheithaeuer BW, Budka H, von Deimling A and Kepes JJ: Meningiomas. In: Pathology \& Genetics: Tumours of the Nervous System. Kleihues P and Cavenee WK (eds). World Health Organization Classification of Tumours, IARC Press, France, 2000.

3. Zang KD: Meningioma: A cytogenetic model of a complex benign human tumor, including data on 394 karyotyped cases. Cytogenet Cell Genet 93: 207-220, 2001.

4. Perry A, Gutmann DH and Reifenberger G: Molecular pathogenesis of meningiomas. Review. J Neurooncol 70: 183-202, 2004. 
5. Dumanski JP, Carlbom E, Collins VP and Nordenskjold M: Deletion mapping of a locus on human chromosome 22 involved in the oncogenesis of meningioma. Proc Natl Acad Sci USA 84: 9275-9279, 1987

6. Cai DX, Banerjee R, Scheithauer BW, Lohse CM, KleinschmidtDemasters BK and Perry A: Chromosome 1p and 14q FISH analysis in clinicopathologic subsets of meningioma: diagnostic and prognostic implications. J Neuropathol Exp Neurol 60: 628-636, 2001.

7. Perry A, Banerjee R, Lohse CM, Kleinschmidt-Demasters BK and Scheithauer BW: A role for chromosome 9p21 deletions in the malignant progression of meningiomas and the prognosis of anaplastic meningiomas. Brain Pathol 12: 183-190, 2002.

8. Watson M, Gutmann DH, Peterson K, Chicoine MR, KleinschmidtDemasters BK, Brown HG and Perry A: Molecular characterization of human meningiomas by gene expression profiling using high-density oligonucleotide microarrays. Am J Pathol 161: 665-672, 2002.

9. Murakami M, Hashimotos N, Takahashi Y, Hosokawa Y, Inazawa $\mathbf{J}$ and Mineura KA: Consistent region of deletion on 1 p36 in meningiomas: identification and relation to malignant progression. Cancer Genet Cytogenet 140: 99-106, 2003.

10. Lopez-Ginés C, Cerda-Nicolas M, Gil-Benso R, Callaghan R, Collado M, Roldan P and Llombart-Bosch A: Association of loss of $1 \mathrm{p}$ and alterations of chromosome 14 in meningioma progression. Cancer Genet Cytogenet 148: 123-128, 2004.

11. Whittle IR, Smith C, Navoo P and Collie D: Meningiomas. Lancet 363: 1535-1543, 2004.

12. Zang KD: Cytological and cytogenetical studies on human meningiomas. Cancer Genet Cytogenet 6: 249-274, 1982.

13. Bigner SH, Mark J and Bigner DD: Cytogenetics of human brain tumors. Cancer Genet Cytogenet 47: 141-154, 1990.

14. Perry A, Jenkins RB, Dahl RJ, Moertel CA and Scheithauer BW Cytogenetic analysis of aggressive meningiomas: Possible diagnostic and prognostic implications. Cancer 77: 2567-2573, 1996.

15. Bostrom J, Meyer-Puttlitz B, Wolter M, Blaschke B, Weber RG, Lichter P, Ichimura K, Collins VP and Reifenberger G: Alterations of the tumor suppressor genes CDKN2A (pl6INK4a), p14ARF $C D K N 2 B(p 15 I N K 4 b)$, and $C D K N 2 C$ (p18INK4c) in atypical and anaplastic meningiomas. Am J Pathol 159: 661-669, 2001.

16. Ragel BT and Jensen RL: Molecular genetics of meningiomas. Neurosurg Focus 19: E9, 2005.

17. Kleihues P and Cavenee WK (eds): Pathology \& Genetics: Tumours of the Nervous System. World Health Organization Classification of Tumours, IARC Press, France, 2000.

18. Steilen-Gimbe H, Niedermayer I, Feiden W, Freiler A, Steudel W, Zang KD and Henn W: Unbalanced translocation $\mathrm{t}(1 ; 3)(\mathrm{p} 12$ $13 ; q 11)$ in meningiomas as the unique feature of chordoid

19. Yamasaki F, Yoshioka H, Hama S, Sugiyama K, Arita K and Kurisu K: Recurrence of menigiomas. Influence of vascular endothelial growth factor expression. Cancer 89: 1102-1110, 2000

20. Espinosa AB, Tabernero MD, Maíllo A, Sayagués, JM, Ciudad J, Merino M, Alguero MC, Lubombo AM, Sousa P, Santos-Briz A and Orfao A: The cytogenetic relationship between primary and recurrent meningiomas points to the need for new treatment strategies in cases at high risk of relapse. Clin Cancer Res 12 : 772-780, 2006

21. Deimling AV, Larson J, Wellenreuther R, Stangl AP, Velthoven VV, Warnick R, Tew J, Balko G Jr and Menon AG: Clonal origin of recurrent meningiomas. Brain Pathol 9: 645-650, 1999.

22. Hunt DPJ, Freeman A, Morris LS, Burnet NG, Bird K, Davies TW, Laskey RA and Coleman N: Early recurrence of benign meningioma correlates with expression of mini-chromosome maintenance-2 protein. Br J Neurosurg 16: 10-15, 2002

23. Pieroli DA: Análise quantitativa das regiões organizadoras nucleolares (NORs) em carcinomas epidermóides desenvolvidos em hamsters a partir do modelo DMBA-indução com agentes clareadores dentais. PhD Dissertation, Universidade de São Paulo, São Paulo, Brazil, 2003.

24. Filippin C, Chistofolriti LD, Ribeiro MCM and De Lourdes C: Determinação do número de regiões organizadoras de nucléolo (AgNOR) em lesões do epitélio cervical uterino. RBAC 38: 133-139, 2006.

25. Janczukowicz J: The prognostic role of proliferation activity in human CNS tumours: the determination of AgNOR, PCNA and Ki-67 expression. Folia Neuropathol 41: 97-101, 2003.

26. Ahmadi SA and Samadi N: Evaluation of argyrophilic nucleolar organizer region staining in predicting the behavior of meningiomas Ann Saudi Med 26: 38-42, 2006.
27. Pfisterer MK, Hank NC, Preul MC, Hendricks WP, Pueschel J, Coons SW and Sckeck AC: Diagnostic and prognostic significance of genetic regional heterogeneity in meningiomas. Neuro Oncol Res 6: 290-299, 2004.

28. Yakut T, Bekar A, Doygun M, Acar H, Egeli U and Ogul E: Evaluation of relationship between chromosome 22 and p53 gene alterations and the subtype of meningiomas by the Interphase-FISH technique. Teratog Carcinog Mutagen 22: 217-225, 2002.

29. Kleihues P, Louis DN, Scheithauer BW, Rorke LB, Reifenberger G, Burger PC and Cavenee WK: The WHO Classification of Tumors of the Nervous System. J Neuropathol Exp Neurol 61: 215-225, 2002.

30. Leuraud P, Dezamis E, Aguirre-Cruz L, Taillibert S, Lejeune J, Robin E, Mokhtari K, Boch A, Cornu P, Delattre J and Sanson M: Prognostic value of allelic losses and telomerase activity in meningiomas. J Neurosurg 100: 303-309, 2004.

31. Ford CE and Hamerton JL: The chromosomes of man. Nature 178: 1020-1026, 1956.

32. McDonald JD, Daneshvar L, Willert JR, Matsumura K, Waldman F and Cogen PH: Physical mapping of chromosome $17 \mathrm{p} 13.3$ in the region of a putative tumor suppressor gene important in medulloblastoma. Genomics 23: 229-232, 1994.

33. Hui AB, Lo KW, Yin XL, Poon WS and Ng HK: Detection of multiple gene amplifications in glioblastoma multiforme using array-based comparative genomic hybridization. Lab Invest 81: 717-723, 2001.

34. Bodey B, Kaiser HE and Siegel SE: Epidermal growth factor receptor (EGFR) expression in childhood brain tumors. In Vivo 19: 931-941, 2005.

35. Olsen ML, Weaver AK, Ritch PS and Sontheimer H: Modulation of glioma BK channels via erbB2. J Neurosci Res 81: 179-189, 2005.

36. Ebinger M, Senf L and Scheurlen W: Risk stratification in medulloblastoma: screening for molecular markers. Klin Padiatr 218: 139-142, 2006.

37. Novelli A, Sabani M, Caiola A, Digilio MC, Giannotti A, Mingarelli R, Novelli G and Dallapiccola B: Diagnosis of DiGeorge and Williams syndromes using FISH analysis of peripheral blood smears. Mol Cell Probes 13: 303-307, 1999.

38. Liehr T, Thoma K, Kammler K, Gehring C, Ekici A, Bathke KD, Grehl $\mathrm{H}$ and Rautenstrauss B: Direct preparation of uncultured EDTA-treated or heparinised blood for interphase FISH analysis. Appl Cytogenet 21: 185-188, 1995.

39. Carlson JA, Healy K, Tran TA, Malfetano J, Wilson VL, Rohwedder A and Ross JS: Chromosome 17 aneusomy detected by fluorescence in situ hybridization in vulvar squamous cell carcinomas and synchronous vulvar skin. Am J Pathol 157: 973-983, 2000.

40. Howell WM and Black DA: Controlled silver-staining of nucleolus organizer regions with a protective colloidal developer: a 1-step method. Experientia 36: 1014-1015, 1980.

41. Tanaka K, Sato C, Maeda Y, Koike M, Matsutani M, Yamada K and Miyaki M: Establishment of a human malignant meningioma cell line with amplified c-myc oncogene. Cancer 64: 2243-2249, 1989.

42. Wasson JC, Saylors RL III, Zeltzer P, Friedman HS, Bigner SH, Burger PC, Bigner DD, Look AT, Douglass EC and Brodeur GM: Oncogene amplification in pediatric brain tumors. Cancer Res 50: 2987-2990, 1990.

43 Ketter R, Henn W, Feiden W, Prowald A, Sittel C, Steudel WI and Strowitzki M: Nasoethmoidal meningioma with cytogenetic features of tumor aggressiveness in a 16-year-old child. Pediatr Neurosurg 39: 190-194, 2003

44. Ozaki S, Nishizaki T, Ito H and Sasaki K: Comparative genomic hybridization analysis of genetic alterations associated with malignant progression of meningioma. J Neurooncol 41: 167-174, 1999.

45. Heisterkamp N, Morris C and Groffen J: ABR, an active BCRrelated gene. Nucleic Acids Res 17: 8821-8831, 1989.

46. Zhu J, Frosch MP, Busque L, Beggs AH, Dashner K, Gilliland DG and Black PM: Analysis of meningiomas by methylation and transcription based clonality assays. Cancer Res 55: 3865-3872, 1995.

47. Schwechheimer K, Zhou L and Birchmeier W: E-Cadherin in human brain tumours: loss of immunoreactivity in malignant meningiomas. Virchows Arch 432: 163-167, 1998.

48. Schiffer D, Ghimenti C and Fiano V: Absence of histological signs of tumor progression in recurrences of completely resected meningiomas. J Neurooncol 73: 125-130, 2005. 